\title{
Synthesis of 2-aminosuberic acid derivatives as components of some histone deacetylase inhibiting cyclic tetrapeptides
}

\author{
Shital Kumar Chattopadhyay ${ }^{*} \S$, Suman Sil and Jyoti Prasad Mukherjee
}

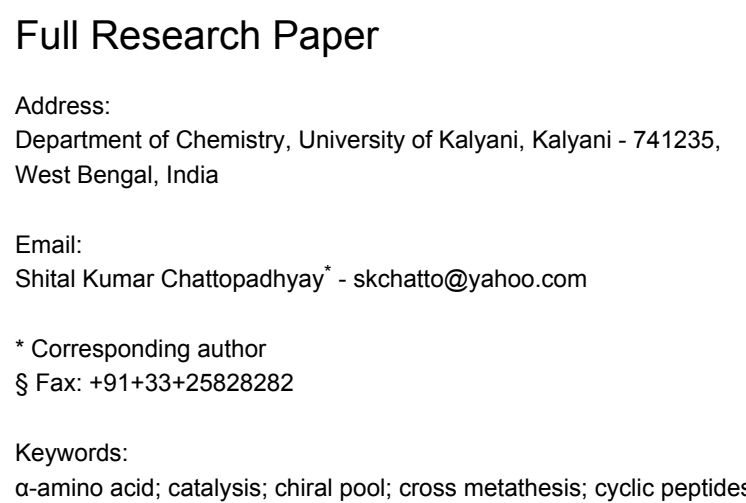

Beilstein J. Org. Chem. 2017, 13, 2153-2156. doi:10.3762/bjoc.13.214

Received: 03 August 2017

Accepted: 25 September 2017

Published: 17 October 2017

Associate Editor: N. Sewald

(c) 2017 Chattopadhyay et al.; licensee Beilstein-Institut. License and terms: see end of document.

\begin{abstract}
A new synthesis of the important amino acid 2-aminosuberic acid from aspartic acid is reported. The methodology involves the alternate preparation of (S)-2-aminohept-6-enoate ester as a building block and its diversification through a cross-metathesis reaction to prepare the title compounds. The utility of the protocol is demonstrated through the preparation of three suberic acid derivatives of relevance to the design and the synthesis of peptides of biological relevance.
\end{abstract}

\section{Introduction}

$\alpha$-Aminosuberic acid (Asu) is a component of apicidin $\mathrm{F}(\mathbf{1}$, Figure 1) belonging to an interesting class of cyclic tetrapeptides displaying antimalarial and histone deacetylase inhibitory (HDACi) properties [1,2]. It has been suggested [3] that the terminal carbonyl group in members of this family (e.g., in 2) functionally mimics the C-8 keto group of the acetylated lysine residue (3) of histones as a part of their biological activity and therefore the variation in the carbonyl functionality may have implications in drug design. Moreover, Asu and its congener 2-aminopimelic acid have been used as ethylenic equivalent of a disulfide linkage [4]. Other applications of Asu in peptide engineering and as a building block are of notable importance $[5,6]$. For this, and other reasons, several synthetic routes to Asu have been developed [7-9] which often uses chemical or enzymatic resolution of a racemate [10]. However, the chemical syn- thesis of an orthogonally protected Asu derivative from easily available sources [11] for potential applications remains important. During the course of our work on the synthesis of amino acids and peptides relevant to HDAC inhibition [12], we required orthogonally protected Asu derivatives. Herein we describe an alternate synthesis of the important building block 2-aminoheptenoic acid and its application to the synthesis of orthogonally protected Asu derivatives.

\section{Results and Discussion}

Our synthesis started with the preparation of bishomoallylglycine derivative 11 (Scheme 1) from the known aspartic acid derived aldehyde 4 [13]. The latter was converted to its doubly homologated derivative 8 through four conventional steps viz. HWE-type olefination leading to the unsaturated ester $\mathbf{5}$, satura- 
<smiles></smiles>

1, apicidin $F$<smiles>CCC(=O)CCCCC[C@H]1NC(=O)[C@@H]2CCCN2C(=O)[C@H](Cc2ccccc2)NC(=O)[C@H](Cc2ccccc2)NC1=O</smiles>

2, FR-225497

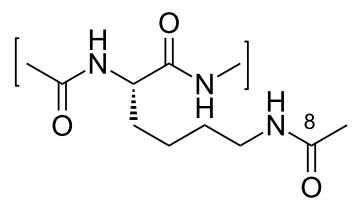

3

Figure 1: Biologically active naturally occurring cyclic tetrapeptide HDAC inhibitors.

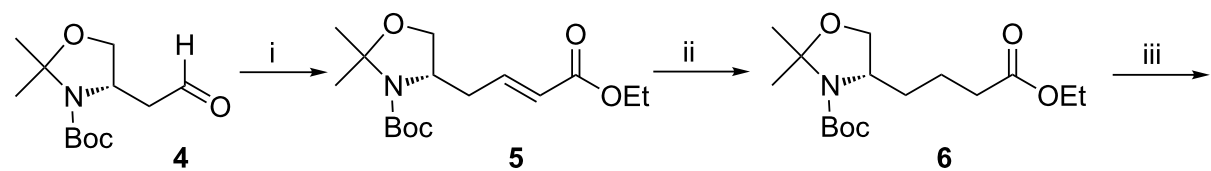

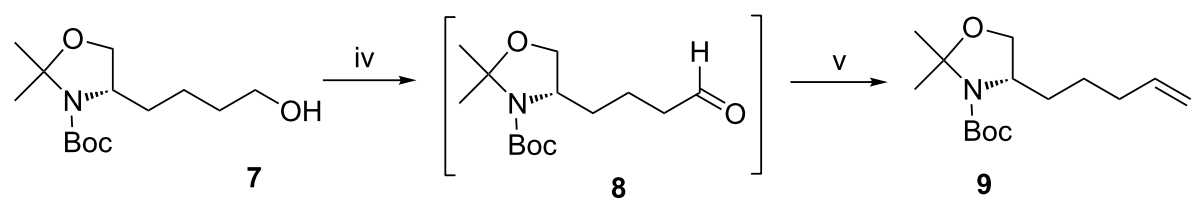<smiles>[R]OC(=O)C(CCCC=C)N[R6](=O)[O-]</smiles>

10, $\mathrm{R}=\mathrm{H}$

11, $\mathrm{R}=\mathrm{Me}$

Scheme 1: Reagents and conditions: (i) Triethyl phosphonoacetate, $n-\mathrm{Bu}_{4} \mathrm{~N}^{+} \mathrm{I}^{-}$, aq $\mathrm{K}_{2} \mathrm{CO}_{3}, \mathrm{rt}, 18 \mathrm{~h}, 86 \%$; (ii) $\mathrm{H} 2, \mathrm{Pd} / \mathrm{C}, \mathrm{EtOAc}, \mathrm{rt}, 6 \mathrm{~h}, 83 \%$; (iii) $\mathrm{LAH}$, THF, $0{ }^{\circ} \mathrm{C}$ to rt, $2 \mathrm{~h}, 81 \%$; (iv) $(\mathrm{COCl})_{2}$, DMSO, $\mathrm{N}$-methylmorpholine, $\mathrm{CH}_{2} \mathrm{Cl}_{2},-78{ }^{\circ} \mathrm{C}$ to $0{ }^{\circ} \mathrm{C}$; (v) $\mathrm{MePh}_{3} \mathrm{PBr}, n$-BuLi, THF, $0{ }^{\circ} \mathrm{C}, 3 \mathrm{~h}, 72 \%$ over two steps; (vi) chromic acid, acetone, $2 \mathrm{~h}, 73 \%$; (vii) $\mathrm{Cs}_{2} \mathrm{CO}_{3}, \mathrm{CH}_{3}$ l, DMF, $2 \mathrm{~h}, 88 \%$.

tion of the double bond in the latter to $\mathbf{6}$, reduction of the ester moiety in $\mathbf{6}$ to the alcohol 7 followed by its oxidation. The aldehyde 8 thus obtained was subjected to a Wittig olefination to obtain the desired alkene 9 in an overall yield of $42 \%$ over five steps. One-pot deprotection-oxidation [14] of the oxazolidine moiety in 9 proceeded uneventfully to provide $N$-Boc-2-amino6-heptenoic acid (10) in good yield. The latter was smothly protected as its methyl ester using methyl iodide in the presence of cesium carbonate to provide the desired 2-aminoheptenoic acid derivative 11. Several syntheses of this important amino acid have appeared which include Lubell's palladium-catalyzed allylation [15], Riera's asymmetric epoxidation protocol [16], Rich's enolate amination [17] and Hruby's asymmetric alkylation [18] of a chiral nickel complex among others. Moreover, many of these studies have also reported an elegant use of this unsaturated amino acid [19]. Our simple protocol involves the use of less sophisticated reagents and catalysts and the use of easily available starting materials; it proceeds in an overall yield of $27 \%$ over seven high yielding simple steps.
Having access to the building block 11, we focused on its conversion to the targeted Asu derivatives through cross metathesis (CM) [20] with conjugated olefins 13a-d (Scheme 2). In recent years, the cross-metathesis reaction has emerged as a valuable tool in the preparation of $\alpha$-amino acids [21-27] and few useful general guidelines have emerged from these studies. Pleasingly, cross metathesis of our building block 11 with tertbutyl acrylate (13a) proceeded quickly in the presence of Grubbs' 2nd generation catalyst [(1,3-bis(2,4,6-trimethylphenyl)-2-imidazolidinylidene)dichloro(phenylmethylene)(trichlorohexylphosphine)ruthenium, 12] in refluxing dichloromethane and the product 14a was obtained in good yield. The corresponding reaction of $\mathbf{1 1}$ with benzyl acrylate (13b) proceeded with similar facility, yield and isomeric composition. Although the cross-metathesis reaction with $\alpha, \beta$-unsaturated esters and ketones have been extensively studied, the corresponding reactions with amides and anilides are less documented [28]. An elegant solution to one of this problems is the use of acryloyl chloride as CM partner followed by functionali- 


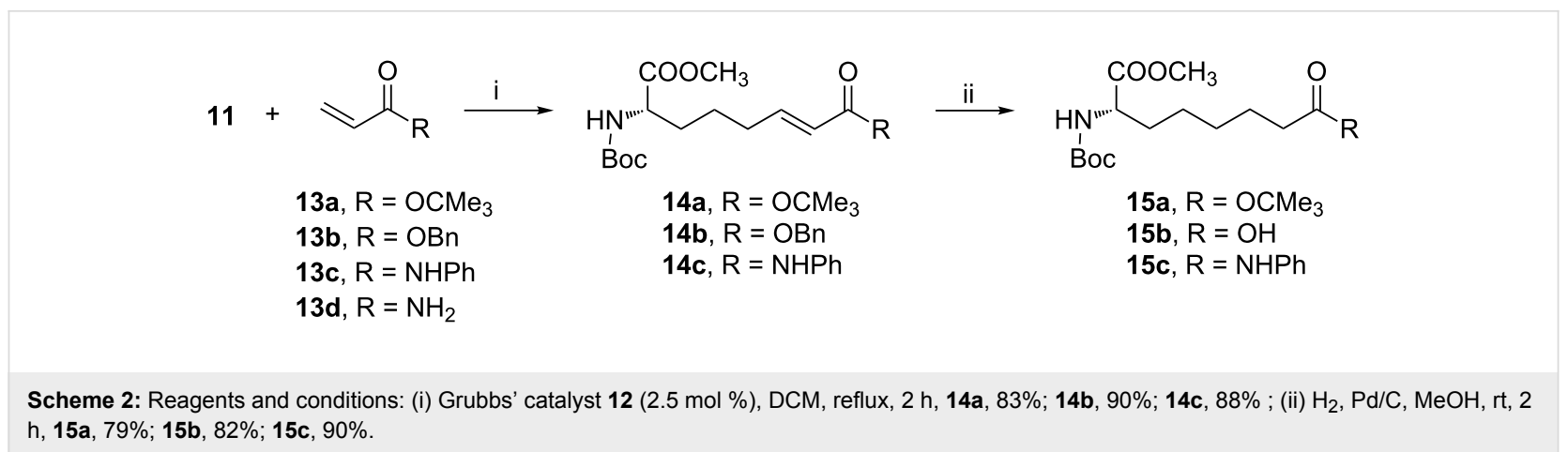

zation of the cross product [29]. To our delight, the reaction of 11 with anilide 13c proceeded well under our developed conditions and the CM product was obtained as a single isomer $(E-)$. Only a few successful reports on cross metathesis with Weinreb's amide of acrylic acid, and N-alkylated acrylamides are known [30-33]. However, all attempts of CM reaction of 11 with the olefin 13d proved to be futile, a major problem being the inadequate solubility of the olefin in the reaction solvents tried, e.g., dichloromethane, dichloroethane, benzene, toluene etc. The solubility problem may be avoided by dilution and increasing the temperature but the reaction is too slow to be useful. The CM product 14a was then hydrogenated to obtain the known Asu derivative 15a [34] under conventional conditions. Similarly, the known $N$-Boc-L-Asu-OH (15b) [35] was obtained by hydrogenation of the benzyl ester $\mathbf{1 4 b}$ with concomitant saturation of the double bond. The conversion of $14 \mathrm{c}$ into 15c proceeded without events.

\section{Conclusion}

In conclusion, we have developed a modestly diversified synthesis of important Asu derivatives through an alternate preparation of the building block $\mathbf{1 1}$ of proven utility in the design and synthesis of peptidomimetics. A cross-metathesis reaction has been utilized to create the diversification on the template $\mathbf{1 1}$ in order to obtain orthogonally protected Asu derivatives. Moreover, the Asu derivative 15a has been demonstrated to be useful in the preparation of a plethora of HDAC inhibitors [34]. The methodology may therefore find application in the synthesis of related targets and may complement to the existing literature. The work will be continued to explore syntheses of other Asu derivatives using the developed methodology.

\section{Experimental}

\section{General procedure for cross metathesis}

This was carried out in a manner as described in [36]. Grubb's second generation catalyst 12 (10 mg, $0.012 \mathrm{mmol}, 2.5 \mathrm{~mol} \%)$ was added to a stirring solution of olefin $11(130 \mathrm{mg}$, $0.50 \mathrm{mmol})$ in dry DCM $(1 \mathrm{~mL})$ and then a solution of the appropriate electron-deficient olefin $13(1.5 \mathrm{mmol})$ in dry DCM
$(1 \mathrm{~mL})$ was added dropwise under an argon atmosphere. The resulting reaction mixture was then heated to reflux for $2 \mathrm{~h}$. The reaction mixture was allowed to cool to room temperature and then concentrated in vacuo. The residue was subjected to column chromatographic purification over silica gel using an appropriate mixture of ethyl acetate in hexane to provide the coupled product as colorless viscous liquid.

\section{$(S, E)$-1-tert-Butyl 8-methyl 7-(tert-butoxy- carbonylamino)oct-2-enedioate (14a)}

Colourless liquid. Yield: $148 \mathrm{mg}, 83 \% ;[\alpha]_{\mathrm{D}}{ }^{25}+12.60$ (c 1.00, $\mathrm{CHCl}_{3}$ ); IR (neat): 3363, 2978, 2933, 1715, 1652, 1505, 1367, $1164 \mathrm{~cm}^{-1} ;{ }^{1} \mathrm{H}$ NMR $\left(400 \mathrm{MHz}, \mathrm{CDCl}_{3}\right) \delta 6.81(\mathrm{td}, J=6.8$, $15.6 \mathrm{~Hz}, 1 \mathrm{H}), 5.74(\mathrm{~d}, J=15.6 \mathrm{~Hz}, 1 \mathrm{H}), 5.10(\mathrm{~d}, J=7.6 \mathrm{~Hz}$, $1 \mathrm{H}), 4.31(\mathrm{~m}, 1 \mathrm{H}), 3.74(\mathrm{~s}, 3 \mathrm{H}), 2.23-2.17(\mathrm{~m}, 2 \mathrm{H}), 1.81(\mathrm{~m}$, 1H), $1.65(\mathrm{~m}, 1 \mathrm{H}), 1.58-1.48(\mathrm{~m}, 11 \mathrm{H}), 1.44(\mathrm{~s}, 9 \mathrm{H}) \mathrm{ppm} ;{ }^{13} \mathrm{C}$ NMR $\left(100 \mathrm{MHz}, \mathrm{CDCl}_{3}\right) \delta 173.2,165.9,155.3,146.7,123.6$, 80.1, 79.9, 53.1, 52.3, 32.2, 31.4, 28.3, 28.1, 23.8 ppm; HRMS $\left(\mathrm{TOF}-\mathrm{MS} \mathrm{ES}{ }^{+}\right) \mathrm{m} / \mathrm{z}:[\mathrm{M}+\mathrm{Na}]^{+}$calcd for $\mathrm{C}_{18} \mathrm{H}_{31} \mathrm{NNaO}_{6}$, 380.2049 ; found, 380.2056 .

\section{Supporting Information}

\section{Supporting Information File 1}

Experimental details and analytical data of all new compounds as well as copies of their ${ }^{1} \mathrm{H}$ and ${ }^{13} \mathrm{C}$ NMR spectra.

[http://www.beilstein-journals.org/bjoc/content/ supplementary/1860-5397-13-214-S1.pdf]

\section{Acknowledgements}

We are thankful to CSIR, New Delhi, for funds (02/0164/13/ EMR-II), and fellowship to two of us (JPM, SS).

\section{References}

1. von Bargen, K. W.; Niehaus, E.-M.; Bergander, K.; Brun, R.; Tudzynski, B.; Humpf, H.-U. J. Nat. Prod. 2013, 76, 2136-2140. doi:10.1021/np4006053 
2. Abe, F.; Hino, M.; Mori, H.; Takase, S.; Yoshimura, S. Inhibitor of Histone Deacetylase. WO Pat. Appl. WO 2000008048 A2, Feb 17, 2000.

3. Pazin, M. J.; Kadonaga, J. T. Cell 1997, 89, 325-328. doi:10.1016/S0092-8674(00)80211-1

4. Nutt, R. F.; Strachan, R. G.; Veber, D. F.; Holly, F. W. J. Org. Chem. 1980, 45, 3078-3080. doi:10.1021/jo01303a028

5. Gut, V.; Čeřovský, V.; Žertová, M.; Körblová, E.; Maloň, P.; Stocker, H.; Wünsch, E. Amino Acids 2001, 21, 255-263. doi:10.1007/s007260170011

6. Rich, D. H.; Singh, J.; Gardner, J. H. J. Org. Chem. 1983, 48, 432-434. doi:10.1021/jo00152a005

7. Wernic, D.; DiMaio, J.; Adams, J. J. Org. Chem. 1989, 54, 4224-4228. doi:10.1021/jo00278a046

8. Miao, W.; Xu, W.-L.; Zhang, Z.-L.; Chen, S.-H.; Li, G. Chin. J. Org. Chem. 2007, 27, 1264-1267.

9. Castejón, P.; Moyano, A.; Pericàs, M. A.; Riera, A. Synth. Commun. 1994, 24, 1231-1238. doi:10.1080/00397919408011722

10. Agosta, E.; Caligiuri, A.; D’Arrigo, P.; Servi, S.; Tessaro, D.; Canevotti, R. Tetrahedron: Asymmetry 2006, 17, 1995-1999. doi:10.1016/j.tetasy.2006.07.012

11. O'Connor, C. J.; Beckmann, H. S. G.; Spring, D. R. Chem. Soc. Rev. 2012, 41, 4444-4456. doi:10.1039/c2cs35023h See for a review.

12. Mukherjee, J.; Sil, S.; Chattopadhyay, S. K. Beilstein J. Org. Chem 2015, 11, 2487-2492. doi:10.3762/bjoc. 11.270

13. Sarkar, K.; Singha, S. K.; Chattopadhyay, S. K. Tetrahedron: Asymmetry 2009, 20, 1719-1721. doi:10.1016/j.tetasy.2009.06.021

14. Chattopadhyay, S. K.; Sarkar, K.; Thander, L.; Roy, S. P. Tetrahedron Lett. 2007, 48, 6113-6116. doi:10.1016/j.tetlet.2007.06.148

15. Prasad Atmuri, N. D.; Lubell, W. D. J. Org. Chem. 2015, 80, 4904-4918. doi:10.1021/acs.joc.5b00237

16. Alcón, M.; Moyano, A.; Pericàs, M. A.; Riera, A. Tetrahedron: Asymmetry 1999, 10, 4639-4651. doi:10.1016/S0957-4166(99)00525-X

17. Ripka, A. S.; Bohacek, R. S.; Rich, D. H. Bioorg. Med. Chem. Lett. 1998, 8, 357-360. doi:10.1016/S0960-894X(98)00025-0

18. Gu, X.; Ndungu, J. M.; Qu, W.; Ying, J.; Carducci, M. D.; Wooden, H.; Hruby, V. J. Tetrahedron 2004, 60, 8233-8243. doi:10.1016/j.tet.2004.06.087

19. Yeo, D. J.; Warriner, S. L.; Wilson, A. J. Chem. Commun. 2013, 49, 9131-9133. doi:10.1039/c3cc45231j

20. Żukowska, K.; Grela, K. Cross Metathesis. In Comprehensive Organic Synthesis II, 2nd ed.; Knochel, P.; Molander, G. A., Eds.; Elsevier, 2014; Vol. 5, pp 1257-1301. doi:10.1016/B978-0-08-097742-3.00527-9 See for a review.

21. Wang, Z. J.; Jackson, W. R.; Robinson, A. J. Org. Lett. 2013, 15, 3006-3009. doi:10.1021/ol401194h

22. Tsuruda, T.; Ebine, M.; Umeda, A.; Oishi, T. J. Org. Chem. 2015, 80, 859-871. doi:10.1021/jo502322m

23. Zhang, Y.; Dlugosch, M.; Jübermann, M.; Banwell, M. G.; Ward, J. S. J. Org. Chem. 2015, 80, 4828-4833. doi:10.1021/acs.joc.5b00590

24. Jayasinghe, S.; Venukadasula, P. K. M.; Hanson, P. R. Org. Lett. 2014, 16, 122-125. doi:10.1021/ol403110p

25. Nair, R. N.; Bannister, T. D. J. Org. Chem. 2014, 79, 1467-1472. doi:10.1021/j04023606
26. Gibson, S. E.; Gibson, V. C.; Keen, S. P. Chem. Commun. 1997, 1107-1108. doi:10.1039/a702027i

See for an earlier example.

27. Saha, N.; Chatterjee, B.; Chattopadhyay, S. K. J. Org. Chem. 2015, 80, 1896-1904. doi:10.1021/jo5022162

See for an example from our laboratory.

28. O'Leary, D. J.; O'Neil, G. W. Cross-Metathesis. Grubbs, R. H.; Wenzel, A. G.; O'Leary, D. J.; Khosravi, E., Eds.; Handbook of Metathesis, Vol. 2; Wiley-VCH Verlag GmbH \& Co. KGaA: Weinheim, Germany, 2015; pp 171-294.

See for a discussion on the topic.

29. Ferrié, L.; Bouzbouz, S.; Cossy, J. Org. Lett. 2009, 11, 5446-5448. doi:10.1021/ol9021386

30. Boufroura, H.; Mauduit, M.; Drège, E.; Joseph, D. J. Org. Chem. 2013, 78, 2346-2354. doi:10.1021/jo302435a See for CM with Weinreb's amide.

31. Bilel, H.; Hamdi, V.; Zagrouba, F.; Fischmeister, C.; Bruneau, C. RSC Adv. 2012, 2, 9584-9589. doi:10.1039/c2ra21638h See for a greener aspect of CM with electron defiecient olefins.

32. Bidange, J.; Fischmeister, C.; Bruneau, C.; Dubois, J.-L.; Couturier, J.-L. Monatsh. Chem. 2015, 146, 1107-1113. doi:10.1007/s00706-015-1480-1 See for a detailed study of CM with acrylonitrile.

33. Guan, J.; Hachey, M.; Puri, L.; Howieson, V.; Saliba, K. J.; Auclair, K. Beilstein J. Org. Chem. 2016, 12, 963-968. doi:10.3762/bjoc.12.95 See for a recent report of $\mathrm{CM}$ with $\mathrm{N}$-alkylated acrylamides.

34. Attenni, B.; Ferrigno, F.; Jones, P.; Ingenito, R.; Kinzel, O.; Llauger, B. L.; Jesus, O.; Pescatore, G.; Rowley, M.; Scarpelli, R.; Schultz, C. Preparation of heterocycle derivatives as histone acetylase inhibitors. WO Pat. Appl. WO 2006061638 A2, June 15, 2006.

35. Nishino, N.; Arai, T.; Ueno, Y.; Ohba, M. Chem. Pharm. Bull. 1996, 44, 212-214. doi:10.1248/cpb.44.212

36. Mukherjee, J. P.; Sil, S.; Chattopadhyay, S. K. Tetrahedron Lett. 2016, 57, 739-742. doi:10.1016/j.tetlet.2016.01.005

\section{License and Terms}

This is an Open Access article under the terms of the Creative Commons Attribution License (http://creativecommons.org/licenses/by/4.0), which permits unrestricted use, distribution, and reproduction in any medium, provided the original work is properly cited.

The license is subject to the Beilstein Journal of Organic Chemistry terms and conditions:

(http://www.beilstein-journals.org/bjoc)

The definitive version of this article is the electronic one which can be found at: $\underline{\text { doi:10.3762/bjoc. } 13.214}$ 